\title{
Black beetle damage to perennial ryegrass infected with AR1 endophyte
}

\author{
A.J. POPAY and J.G. BALTUS \\ AgResearch, Ruakura Research Centre, Private Bag 3123, Hamilton
}

alison.popay@agresearch.co.nz

\begin{abstract}
AR1 is a new fungal endophyte that is being released in perennial ryegrass to New Zealand farmers. This endophyte lacks the mammalian toxins, ergovaline and lolitrem $\mathrm{B}$, but produces peramine which provides resistance to a major ryegrass pest, Argentine stem weevil (Listronotus bonariensis). Black beetle (Heteronychus arator) is another important pest of ryegrass in northern areas of New Zealand. Adults are selective feeders, and avoid feeding on ryegrass infected with wildtype endophyte. A limited supply of suitable food greatly reduces their reproductive capacity. Laboratory and field investigations were therefore carried out to evaluate the degree of resistance to black beetle provided by AR1.
\end{abstract}

Assessments of adult black beetle feeding were made on two field trials planted in autumn 1999. In both trials, adult feeding was significantly higher on ryegrass infected with AR1 than on ryegrass with wild-type but also significantly lower on AR1 than on endophyte-free ryegrass. In a pot trial conducted in summer, black beetle adult damage to 4-week-old AR1-infected ryegrass was no different from damage to endophyte-free plants. However in 6-month-old plants, damage to AR1 plants was significantly less than to endophyte-free plants and was similar to damage levels on wild-type plants. A further pot trial showed that beetles overwintering on AR1 ryegrass had a higher reproductive capacity than those overwintering on wild-type infected ryegrass. In February 2001, two field trials planted the previous June were sampled for black beetle larvae. Black beetle presence was significantly higher on endophyte-free plots than on wild-type plots, with presence on AR1 intermediate between these treatments.

Ryegrass infected with AR1, although showing a degree of resistance to black beetle compared with endophyte-free ryegrass, is more susceptible to damage than wild-type, particularly in its first year of planting. Limited data indicate that older AR1 swards may have similar resistance to that of the wild-type but further research is needed to clarify the effect of stand maturity on black beetle damage to ryegrass infected with this new endophyte.

Keywords: AR1, black beetle, endophyte, Heteronychus, Listronotus, Neotyphodium, ryegrass

\section{Introduction}

Black beetle (Heteronychus arator) is a major, though sporadic, pest of ryegrass (Lolium perenne) pastures from the Waikato and Bay of Plenty regions northwards. Key factors influencing the occurrence of outbreaks include soil temperatures in spring and summer and soil moisture levels (King et al. 1981a; East et al. 1981). Larvae feed close to the soil surface on the roots of grasses during summer, and in ryegrass this leads to the death of crowns during drought or from subsequent pulling by grazing animals. Adult black beetles can also cause significant pasture loss by chewing at the base of tillers (Watson \& Marsden 1982) and can destroy new autumn sowings of susceptible grasses in heavily infested ground. Female fecundity is determined by the fat levels built up while feeding on favourable hosts, including ryegrass, and oviposition sites are also influenced by host preference (King et al. 1981b).

Adult black beetle is deterred from feeding on ryegrass by the presence of endophyte (Neotyphodium lolii), an effect which leads to fewer eggs being laid in wild-type infected ryegrass pastures (Ball \& Prestidge 1992). Larvae are thought not to be affected directly by the fungus (Popay \& Ball 1998) and this means that even wild-type infected pastures can suffer considerable black beetle larval damage when alternative hosts for the adult, such as paspalum (Paspalum dilatatum) and poa (Роа апnиа), are present. Of the known alkaloids produced by $N$. lolii, only ergovaline has been found to be active against black beetle adults (Ball et al. 1997). Low levels, or absence, of this alkaloid in endophyteinfected ryegrass pastures could therefore make them more susceptible to black beetle damage. The new endophyte strain AR1, now commercially available in several ryegrass cultivars, does not produce either ergovaline or lolitrem $\mathrm{B}$, both of which are mammalian toxins. Ryegrass infected with this endophyte is highly resistant to Argentine stem weevil (Listronotus 
bonariensis). The effect that ryegrass infected with AR1 has on adult black beetle feeding and fecundity and on larval damage in its first year after planting is described in this paper.

\section{Methods}

The effect of AR1 endophyte on adult black beetle damage was assessed in seedling ryegrass at two sites and also in two pot trials that examined the effect of plant age and endophyte on feeding and reproduction. Larval black beetle densities were measured in two field trials. In each trial, AR1 was compared with endophyte-free ryegrass and ryegrass infected with wildtype endophyte.

\section{Adult damage to newly-sown pasture}

Perennial ryegrass cv Vedette, was sown at $20 \mathrm{~kg} / \mathrm{ha}$ at Dexcel in Hamilton in twelve 0.25 ha paddocks for each treatment on $22 \& 23$ April 1999. On 31 May 1999 , the total number of seedlings and the number of seedlings damaged by adult black beetle was determined in ten randomly selected $30-\mathrm{cm}$ row lengths in each of six paddocks per treatment. Seedlings were deemed to be damaged if they had fallen or were easily removed from the base and had the shredding typical of black beetle adult feeding. One-hundred tillers were harvested randomly from each treatment and the percent endophyte infection levels were ascertained by immunoblot. Total and damaged seedling numbers (untransformed data) were analysed by ANOVA.

In a second trial, six ryegrass cultivars were sown at $20 \mathrm{~kg} / \mathrm{ha}$ in March 1999 at Ruakura Research Centre, Hamilton. Plot size was $3 \mathrm{~m} \times 2 \mathrm{~m}$ and there were four replicates of each cultivar/endophyte treatment arranged in a randomised block design. On 29 May 1999, the plots were scored for adult black beetle damage on a scale of $0-5$ on the basis of the number of tillers showing yellowing, with 5 being the most severe. Yellowing is a symptom of adult black beetle damage and several such tillers were examined in each plot to confirm that beetle feeding was the cause. In November 1999, 20 tillers were taken randomly from each plot and tested for the presence of endophyte using the immunoblot method. Damage scores were subjected to ANOVA after log transformation.

\section{Plant age and black beetle adult feeding}

Germinated seeds of perennial ryegrass cv. Samson were planted into buckets $(250 \mathrm{~mm}$ diam., $260 \mathrm{~mm}$ high) filled with $15 \mathrm{~cm}$ of soil on 20 October 1999 and held in a shadehouse. Plants were to be assessed for their effects on beetle adults at 4 weeks and 6 months of age. Ten seeds were planted in each bucket for the 4-week-old test and five seeds for the older plants. There were eight replicates of each endophyte treatment, for each plant age tested. After 4 weeks or 6 months of growth, six field-collected adult black beetles (three male and three female) were introduced to each bucket. One week later, and again after a fortnight, the numbers of damaged and undamaged tillers on each plant were recorded. Endophyte status was determined by microscopic examination of leaf sheath tissue.

\section{Black beetle reproduction}

Germinated seed of perennial ryegrass cv. Samson was sown into $15-\mathrm{cm}$-diam. pots filled to the brim with a commercial potting mix medium on 20 April 2000 and retained in a shadehouse at Ruakura. A month after planting, eight replicate pots for each endophyte type were placed in buckets ( $250 \mathrm{~mm}$ diam., $260 \mathrm{~mm}$ high) of sand, so that the top of the pot was level with the top of the sand. Endophyte checks were made on plants by microscopic examination of leaf sheath tissue. Any plants in endophyte-infected treatments that were found not to be infected were replaced. Three female and three male field-collected black beetles were introduced to each pot. In mid-June 2000, the total tillers per plant and the number damaged by black beetle adult feeding were counted. Beetles were then removed to fresh plants. This process was repeated five more times until a final assessment was made on 30 October 2000. At this time the eggs were extracted from the sand and potting medium by hand sorting and flotation. Damage data only for this final assessment are presented. After log transformation, data for the percentage of damaged tillers at the final assessment were compared using a generalised linear model with the number of live beetles known to be in the trial at the beginning of the assessment period as a covariate. The number of eggs was analysed without a covariate for live beetles because survival itself was affected by treatment and therefore was a component of reproductive potential.

\section{Black beetle in field trials}

Following application of Roundup ${ }^{\circledR}$, Dicamba ${ }^{\circledR}$ and Versatil ${ }^{\circledR}$ (at 8, 4 and $2.5 \mathrm{~L} / \mathrm{ha}$ respectively) on 24 May 2000, two field trials at Ruakura Research Centre were direct drilled with ryegrass cv. Samson on 6 June 2000 with a double pass of a Duncan's Triple Disc drill to give a sowing rate of $20 \mathrm{~kg} / \mathrm{ha}$. Plots were $3 \mathrm{~m}$ $\mathrm{x} 10 \mathrm{~m}$ in Trial A and $3 \mathrm{~m} \mathrm{x} 9 \mathrm{~m}$ in Trial B with four replicates of each treatment arranged in a randomised block design. Trials were grazed with either sheep or dairy cows as necessary and grazing was followed by an application of $\mathrm{N}$ at $50 \mathrm{~kg} / \mathrm{ha}$. In November all plots were treated with Versatil ${ }^{\circledR}$ and Turfweed ${ }^{\circledR}$ at 1 and 2 $\mathrm{L} /$ ha respectively to control summer grasses and weeds. 
At the same time plots were split and half of each was treated with a granular soil insecticide. Data are not presented for insecticide treatments. Untreated plots were sampled for black beetle in Trial A on 21 February and Trial B on 24 February 2001 by taking 15 cores (100 m diam. x $50 \mathrm{~mm}$ deep) per plot. Cores were hand sorted in the field and all stages of black beetle (eggs to adult) were recorded. Frass, plant damage and tunnelling from black beetle larvae were also recorded as a sign of black beetle damage when no insect stages were present and this was included in the total number of black beetle as representing a single individual in each case. Untransformed data were subjected to ANOVA.

\section{Results}

\section{Adult damage to newly-sown pasture}

In Vedette infected with AR1, the percentage of seedlings damaged by adult black beetle was greater than in wildtype $(\mathrm{P}<0.05)$ but less than in endophyte-free paddocks $(\mathrm{P}<0.05)$ (Table 1). Similarly in the cultivar trial at Ruakura, black beetle damage scores for AR1-infected cultivars were all intermediate between those of wildtype and endophyte-free treatments with the exception of Supreme which had moderate levels of endophyte infection in endophyte-free treatments and only $61 \%$ infection rates in wild-type plots (Table 1). In significant endophyte by cultivar interactions, AR1 had lower damage scores than endophyte-free in Impact and Samson $(\mathrm{P}<0.05)$ but not in the other cultivars. In all cultivars, except Supreme and Marsden, damage scores of AR1 were greater $(\mathrm{P}<0.05)$ than wild-type. As for Supreme, wild-type infection levels in Marsden were at least $20 \%$ below that of the other cultivars. Damage scores were highest in Marsden compared with other cultivars $(\mathrm{P}<0.05)$.

Plant age and adult black beetle feeding.

After 4 weeks, both AR1 and endophyte-free plants had more damaged tillers than wild-type plants $(\mathrm{P}<0.05)$
(Figure 1). At the end of the second week of the test, when damage had increased substantially in all treatments, the percentage of damaged tillers was still much greater on AR1 than on wild-type but these differences were no longer significant. At this time there were more tillers damaged on endophyte-free plants than on wild-type $(\mathrm{P}<0.05)$. In 6-month-old plants both AR1 and wild-type had fewer tillers damaged by black beetle adults $(\mathrm{P}<0.01)$ than endophyte-free ryegrass. Differences between AR1 and wild-type were not significant.

Figure $\llbracket 1$ The effect of plant age on the mean percentage of tillers on Samson ryegrass plants, without endophyte (Nil) or infected with AR1 or wild-type, that were damaged by black beetle after 7 or 14 days. Error bars represent SEM.

$\square$ Nil $\square$ AR1 $\square$ Wild-type

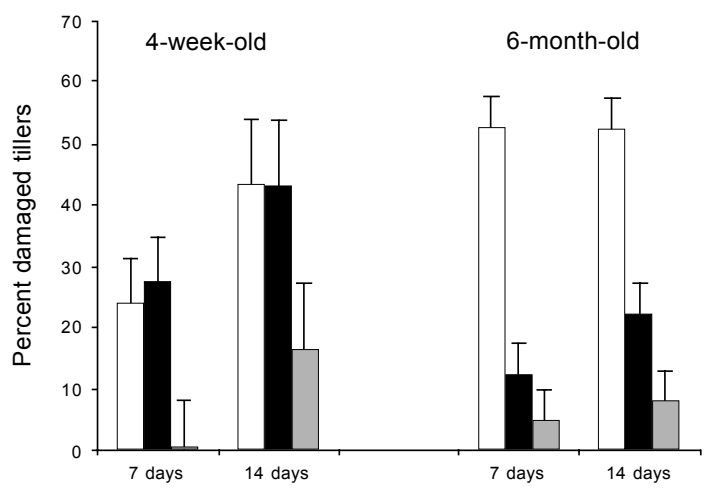

\section{Black beetle reproduction}

There were fewer eggs and damaged tillers on wildtype ryegrass than on AR1 and endophyte-free plants $(\mathrm{P}<0.01)$ with no differences between the latter two treatments (Table 2). Survival of beetles was lower on wild-type than on AR1 but not significantly different from endophyte-free.

Table 1 Black beetle adult damage to ryegrass seedlings of seven cultivars measured in two trials in 1999 and the percent endophyte levels of those cultivars.

\begin{tabular}{|c|c|c|c|c|c|c|c|}
\hline \multirow[t]{2}{*}{ Cultivar } & \multicolumn{4}{|c|}{ 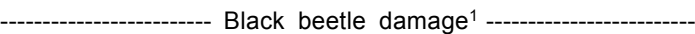 } & \multicolumn{3}{|c|}{--------------- \% Endophyte ${ }^{2}$--------------- } \\
\hline & Nil & AR1 & Wild-type & SED & Nil & AR1 & Wild-type \\
\hline Vedette & 10.3 & 6.5 & 1.8 & 1.78 & 1 & 93 & 93 \\
\hline Samson & 4.4 & 2.5 & 1.2 & 1.16 & 6 & 95 & 86 \\
\hline Nui & 3.9 & 2.9 & 1.2 & 1.16 & 6 & 96 & 99 \\
\hline Pacific & 3.9 & 2.6 & 1.2 & 1.16 & 6 & 94 & 91 \\
\hline Supreme & 3.7 & 2.9 & 2.9 & 1.16 & 31 & 95 & 61 \\
\hline Marsden & 5.2 & 3.5 & 3.2 & 1.16 & 6 & 95 & 66 \\
\hline
\end{tabular}

1 Damage in Vedette was percent damaged seedlings; for all other cultivars damage score was visually estimated on a scale of $0-5$ where 5 is the most severe.

Measured in May 1999 for Vedette and in November 1999 for all other cultivars.

Back-transformed means for all cultivars except Vedette. 
Table $\llbracket 2$ Back-transformed means of the tiller damage, number of eggs and number of live black beetle adults remaining in different endophyte treatments in the reproduction pot trial.

\begin{tabular}{lccc}
\hline Endophyte & $\begin{array}{c}\text { \% tillers } \\
\text { damaged }\end{array}$ & $\begin{array}{c}\text { Mean no. } \\
\text { eggs/plant }\end{array}$ & $\begin{array}{c}\text { Mean no. } \\
\text { live beetles }\end{array}$ \\
\hline Nil & 20.2 & 3.8 & 2.2 \\
AR1 & 15.7 & 4.7 & 3.0 \\
Wild-type & 3.1 & 1.3 & 1.6 \\
SED & 1.693 & 1.428 & 1.8 \\
\hline
\end{tabular}

\section{Black beetle in field trials}

Numbers of black beetle were lower in Trial A than in Trial B (Figure 2). In Trial A, presence of black beetle was recorded mainly as sign of activity (i.e., larval damage, frass and tunnelling) (62\%) whereas in Trial B only $14 \%$ was sign and $86 \%$ live black beetle stages (data not presented). All live black beetles in Trial A and $85 \%$ of those in Trial B were in the larval or pupal stages. In both trials, density of black beetle on AR1 treatments was intermediate between endophyte-free and wild-type and not significantly different from either of them (Figure 2). Black beetle presence was lower on wild-type compared with endophyte-free ryegrass $(\mathrm{P}<0.05)$. Analysis of pooled data from both trials showed black beetle numbers on AR1 were significantly different from numbers on both endophyte-free and the wild-type $(\mathrm{P}<0.05)$.

Figure 2 Black beetle density in two field trials with Samson without endophyte or infected with AR1 or wild-type at Ruakura, Hamilton. Error bars represent SEM.

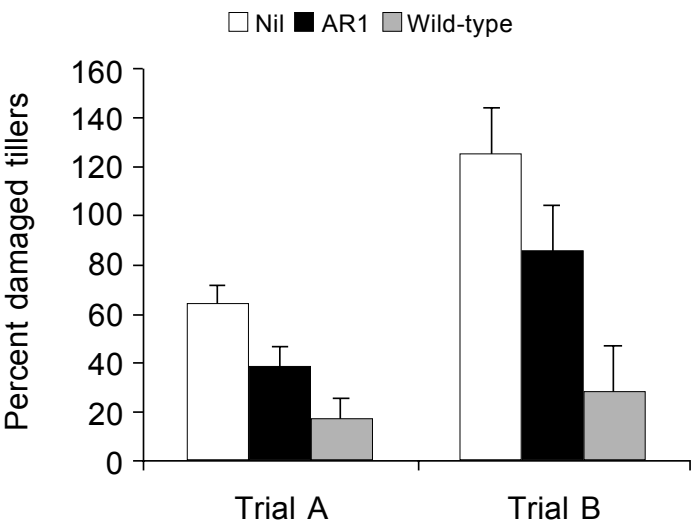

\section{Discussion}

The release of AR1 in New Zealand ryegrass cultivars in autumn 2001 marked a major milestone in the endophyte research programme, which has aimed to provide New Zealand farmers with an endophyte that gives resistance to Argentine stem weevil but causes no animal toxicity, thus lifting animal performance above that which can be achieved with wild-type endophytes. AR1, however, does not produce ergovaline and when Ball et al. (1997) demonstrated that this alkaloid was a feeding deterrent to black beetle adults it became evident that AR1 could be susceptible to this pest. In the last 3 years, black beetle populations have been very high, placing all ryegrass pastures in northern New Zealand under severe pressure. Our results over this period have shown that AR1-infected ryegrass is more vulnerable to black beetle damage than wild-type, at least in its first year of planting. Nevertheless, even in the absence of ergovaline, AR1 has some resistance to adult black beetle when compared to endophyte-free ryegrass and this is reflected in lower larval numbers in the field. It is likely therefore that AR1 produces another compound that affects this pest.

Only in the reproduction trial conducted over winter and early spring were the damage levels for AR1 the same as for endophyte-free ryegrass in plants that were more than 6 months old. Temperature may be a factor in this result since concentrations of alkaloids in the basal component of plants tend to be at their lowest levels from May to September (Ball et al. 1995). In addition plant age appears to influence AR1 resistance to black beetle with older plants being more effective than seedlings at deterring adults. In contrast, endophyte-mediated resistance to Argentine stem weevil is available even in young ryegrass seedlings (Stewart 1985). What is not yet clear is the level of resistance to black beetle that more mature AR1 ryegrass plants may have. In two small-plot field trials at Ruakura and Kerikeri, plant damage by black beetle larvae was measured 2 years after planting and found to be the same on wild-type and AR1 and that damage was significantly less than the damage to endophytefree plots (Popay et al. 1999). While this indicates that mature ryegrass with AR1 is resistant to black beetle, further work is needed to confirm this. Next summer, more information will be obtained when black beetle larval numbers are again assessed on the two field trials at Ruakura. Other work has also shown that the level of resistance to black beetle is more variable among individual plants infected with AR1 than among wild-type plants (Easton et al. 2000). This suggests that it may be possible to select for greater black beetle resistance in AR1-infected ryegrass in the future.

\section{ACKNOWLEDGEMENTS}

Thanks are due to Errol Thom and Stephanie Bluett, Dexcel, for access to their trial, Richard Watson for 
help with sampling and Paul Addison for his willing assistance in collecting black beetle adults. This research was funded by the Foundation for Research, Science and Technology.

\section{REFERENCES}

Ball, O.J-P.; Prestidge, R.A. 1992. The effect of the endophytic fungus Acremonium lolii on adult black beetle (Heteronychus arator) feeding. Proceedings 45th New Zealand Plant Protection Conference: 201-204.

Ball, O.J-P.; Prestidge, R.A.; Sprosen, J.M. 1995. Interrelationships between Acremonium lolii, peramine and lolitrem B in perennial ryegrass. Applied \& Environmental Microbiology 6: 1527-1533.

Ball, O.J-P.; Miles, C.O.; Prestidge, R.A. 1997. Ergopeptine alkaloids and Neotyphodium loliimediated resistance in perennial ryegrass against Heteronychus arator (Coleoptera: Scarabaeidae). Journal of Economic Entomology 90: 1383-1391.

East, R.; King, R.D.; Watson, R.N. 1981. Population studies of grass grub (Costelytra zealandica) and black beetle (Heteronychus arator) (Coleoptera: Scarabaeidae). New Zealand Journal of Ecology 4: $56-64$.

Easton, H.S.; Cooper, B.M.; Lyons, T.B.; Pennell, C.G.; Popay, A.J.; Tapper, B.A. 2000. Selected endophyte and plant variation. Proceedings 4th International Neotyphodium/Grass Interactions Symposium: 351-356.
King, P.D.; Mercer, C.F.; Meekings, J.S. 1981a. Ecology of black beetle Heteronychus arator (Coleoptera: Scarabaeidae) - population studies. New Zealand Journal of Agricultural Research 24: 87-97.

King, P.D.; Mercer, C.F.; Meekings, J.S. 1981b. Ecology of black beetle Heteronychus arator (Coleoptera: Scarabaeidae) - influence of pasture species on oviposition site preference. New Zealand Journal of Zoology 8:119-122.

Popay, A.J.; Ball O-J.P. 1998. The development of fungal endophytes as a pest management tool for New Zealand grasslands. Proceedings of the 6th Australasian Applied Entomological Research Conference (Vol.1): 374-371.

Popay, A.J.; Hume, D.E.; Baltus, J.G.; Latch, G.C.M.; Tapper, B.A.; Lyons, T.B.; Cooper, B.M.; Pennell, C.G.; Eerens, J.P.J.; Marshall, S.L. 1999. Field performance of perennial ryegrass (Lolium perenne) infected with toxin-free fungal endophyte (Neotyphodium spp.). Ryegrass endophyte: an essential New Zealand symbiosis. Grassland Research and Practice Series No. 7: 113-122.

Stewart, A.V. 1985. Perennial ryegrass seedling resistance to Argentine stem weevil. New Zealand Journal of Agricultural Research 28: 403-407.

Watson, R.N.; Marsden R.S. 1982. Effects of adult black beetle (Coleoptera: Scarabaeidae) feeding on two grass species. Proceedings of the $3 \mathrm{rd}$ Australasian Conference on Grassland Invertebrate Ecology: 107-115. 